\title{
Immunohisto chemical Study of Colonic Stem Cells Using Lgr5 and CD133 Proteins in Malignant and Pre Malignant Colonic Lesions
}

\author{
SAED ROSIQ, M.D. ${ }^{\mathbf{~}}$; OLFAT HAMMAM, M.D. ${ }^{\mathbf{2}}$; AHMED ABD EL-ALIM, M.D. ${ }^{\mathbf{1}}$; \\ SAED EL-SHORBAGY, M.D. ${ }^{3}$ and MOSBAH AMER, M.Sc. ${ }^{4}$ \\ The Department of Tropical Medicine, Faculty of Medicine, Al-Azhar University ${ }^{1}$ \\ The Department of Pathology, Theodor Bilharz Research Institute ${ }^{2}$, \\ The Department of Clinical Pathology, Al-Azhar University ${ }^{3}$ and Nasser Institute Hospital ${ }^{4}$, Egypt
}

\begin{abstract}
Background: Colorectal cancer is the fourth common tumor in Egypt after lymphoid, breast and urinary tumors. The aim of the study to assess the expression of Lgr5 and CD133 in pre-malignant (adenomatous polyps and IBD), malignant colorectal lesions and normal colonic mucosa by immunohistochemicalstaining.0
\end{abstract}

Material and Methods: This prospective study was done on 100 patients presenting with colonic symptoms, patients were divided into four groups; Group I including 20 patients in the control group, Group II including 20 Ulcerative Colitis (U.C) patients, Group III including 20 patients with adenomatous polyps and Group IV including 40 patients with Colorectal Cancer (CRC).

Results: Lgr5 and CD133 expression was significantly higher in carcinoma than in adenomas, IBD and normal mucosa $(p<0.001)$. Lrg5 and CD133 was positivelycorrelated with histological grade $(p=0.001)$, depth of invasion $(p=0.001)$ lymph node metastasis $(p<0.001)$, distant metastasis $(p<0.004)$ and TNM stage $(p<0.001)$.

Conclusion: Role of Lgr5 and CD133 as stem cell marker was expressed and presented with different expression in normal colonic mucosa, adenoma and CRC and showed increased expression in advanced stage of CRC. This may suggest its possible involvement in colorectal tumorigenesis and invasion.

Key Words: Colonic cancer - Lgr5 - CD133 - IHC - Polyp.

\section{Introduction}

MANY evidences suggest that cancer is a disease of stem cells $[1,2]$. The cancer stem cell model was described for hematologic malignancies in 1997 and since then evidence has emerged to support it for many solid tumors as well, including colon cancer, this model proposes that certain cells within

Correspondence to: Dr. Saed Rosiq, The Department of Tropical Medicine, Faculty of Medicine, Al-Azhar University, Egypt the tumor mass are pluripotent and capable of selfrenewal and have an enhanced ability to initiate distant metastasis. Becker et al., [4] in their study suggest that (1) Lgr5 is a potential marker of intestinal stem cells in humans and (2) Loss of restriction to the stem cell niche is an early event in the premalignant transformation of stem cells and may play a role in carcinogenesis. Femia et al., [5] found over expression of Lgr5 in precancerous lesions and tumours, they support Lgr5 as putative neoplastic stem cell marker, they identified Lgr5-positive cells co-expression Nuclear 0 . Catenin (NBC) which could be a subpopulation with the highest stem cell features. CD133 (Prominin-1), a transmembrane glycoprotein which was first identified as a potential Cancer Stem Cell (CSC) marker for brain tumors [6]. Both O'Brien et al., [7] and Ricci-Vitiani et al., [8] found that the tumors formed from CD133 positive cells injected intosevere combined immunodeficiency (SCID) mice resembled the tumor from which they were taken and formed tumors of differentiated cell types that were mostly CD133 negative. The CD133 negative cells from these tumors did not form metastases in mice even when injected at much higher numbers than CD133 positive cells.

This aim of the study is designed to investigate the distribution and expression of immunostaining of Lgr5 and CD133 proteins in stem cells of human colon in malignant and pre malignant colonic lesions in Egyptian patients.

\section{Patients and Methods}

This prospective case-control study was conducted on 100 subjects who attended the Gastrointestinal Endoscopy Unit in Nasser Institute for 
Research and Treatment Hospital, and in Collaboration with Theodor Bilharz Research Institute, during the period from March 2015 to March 2017. Patients were categorized into four groups:

Group I: Included 20 patients had normal colonoscopy and served as a control group.

Group II: Included 20 patients with IBD (ulcerative colitis) diagnosed endoscopicaly and pathologically.

Group III: Included 20 patients who were found to have colorectal polyps endoscopicaly and proved to be adenomatous pathologically and served as adenoma group.

Group IV: Included 40 patients with colorectal cancer diagnosed endoscopicaly and pathologically.

Inclusion criteria: Adult patients $>18$ years old and have eligible indications for colonoscopy as follow:

- Patient with lower GIT symptoms including chronic diarrhea, chronic constipation, alternating bowel habits and bleeding per rectum.

- Cases with relevant alarming symptoms and signs for CRC e.g. significant unexplained weight loss, unexplained anemia.

- Patients with remote metastases proved to be adenocarcinoma and were suspected to have CRC.

- Patients underwent screening for CRC.

- Patients who have a family or personal history of CRC, genetic CRC syndrome or adenomas.

- Patients with inflammatory bowel diseases were diagnosed for more than 8 years.

- Patients known to have FAP, family history of FAP or history of previous adenomatous polyps.

Exclusion criteria: Patients previously received chemotherapy for colorectal malignancy.

Patients subjected to the following: Informed written consent, full history taking and thorough clinical examination (pallor, abdominal masses). Laboratory investigation including stool analysis, Complete Blood Count (CBC), Erythrocyte Sedimentation Rate (ESR) and Carcino Embryonic Antigen (CEA). Radiological investigations including abdominal ultrasound (searching for metastases, masses or abdominallymphadenopathy). Full colonoscopic examination by usig of Pentax colonoscope by model number (EC $3840 \mathrm{~L}$ ).

Tissue samples (biopsy specimens): Biopsies were taken from the inspected lesions and the nearby normal colonic mucosa. Biopsies were taken using a standard cold biopsy forceps (CFB2.5-230-S, Wilson Cook medical $\left.{ }^{\circledR}\right)$. In the Control Group multiple biopsies were taken from the colonic mucosa in all cases while in IBD group multiple biopsies were taken from the inflamed mucosa and multiple biopsies were taken from the nearby grossly normal colonic mucosa while in Adenomas group polyps will be removed using a polypectomy snare and multiple biopsies were taken from the nearby mucosa and in CRC group multiple biopsies were taken from the cancer and multiple biopsies from the nearby mucosa.

\section{Specimen collection and handling:}

Specimens were fixed in $10 \%$ buffered formalin. Paraffin blocks were prepared. Histopathologic sections were cut at $4 \mathrm{gm}$ thick. All slides were treated with 3-amino-propyl-triethoxysilane (3APTES/SIGMA-A-3648). These slides were used instead of the ordinary albumenized slides to minimize staining artifacts and for better fixation of sections on the slides.

Immunohistochemistry staining for detection of Lgr5 and CD133 antigens:

Immunohistochemical reaction was performed using Avidin Biotin Complex (ABC) immunoperoxidase technique according to Hsu and Raine (27). Sections were de-waxed in xylene, and hydrated in descending grades of ethanol. Endogenous peroxidase activity was quenched by incubation in 3\% hydrogen peroxide and then in 100\% methanol for 20 minutes. Antigen retrieval was performed by microwaving the sections in citrate buffer (PH 6.0) for 15 minutes at 700W. Sections were incubated overnight at $40 \mathrm{C}$ with the antihuman primary monoclonal antibodies against Lgr5 and CD133 (Santa Cruz Biotechnology Inc.; Santa Cruz, USA) and diluted at 1:100 and 1:150 respectively. Next day, sections were washed in PBS then incubated with streptavidin-biotin peroxidase complex and substantiated using a peroxidase/DAB (diaminobenzidine) enzymatic reaction for Lgr5 and CD133. Staining was completed by 5 to 10 minutes incubation with 3, 3'-Diaminobenzidine $(\mathrm{DAB})+$ substrate-chromogen which resulted in a brown-colored precipitate at the antigen sites of Lrg5 and CD133 (cytoplasmic stain). Slides were washed in PBS for five minutes then placed in $70 \%, 95 \%$ and $100 \%$ alcohol for five minutes each. The nuclei were counterstained with Mayer's hematoxylin. Cover slips were mounted using Dpx. Positive and negative control slides for each marker were included within each session. As a negative control, liver tissue section was processed in the 
above-mentioned sequences but with omission of the primary antibodies.

\section{Lgr5 and CD133 immunostaining interpretation:}

All immunostained slides were analyzed using Zeis microscope with high resolution (Axio Scope, Germany) in ten successive High-Power Fields (HPFs). Both Lgr5 and CD133 antigens were expressed as brown cytoplasmic staining. Two features of immuno-reactions were assessed separately on a semi-quantitative basis (H score) as follows:

1- The extent of staining was assessed as the percentage of positively stained cells in $10 \mathrm{HPFs}$ in the highest expression (hot spot) areas in each case. Then, means of percentages were calculated.

2- The intensity of staining of the positive cells was relatively designated as + (mild or weak), ++ (moderate), and +++ (strong) according to Itoi Het al. Then data were converted to immunohistochemical score (ranged from 1 to 6 ) by

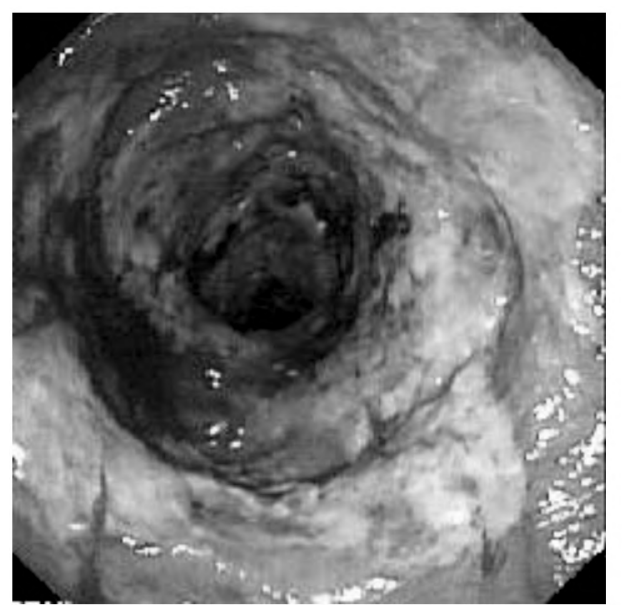

Fig. (1): Case of ulcerative colitis with rectal involvement.

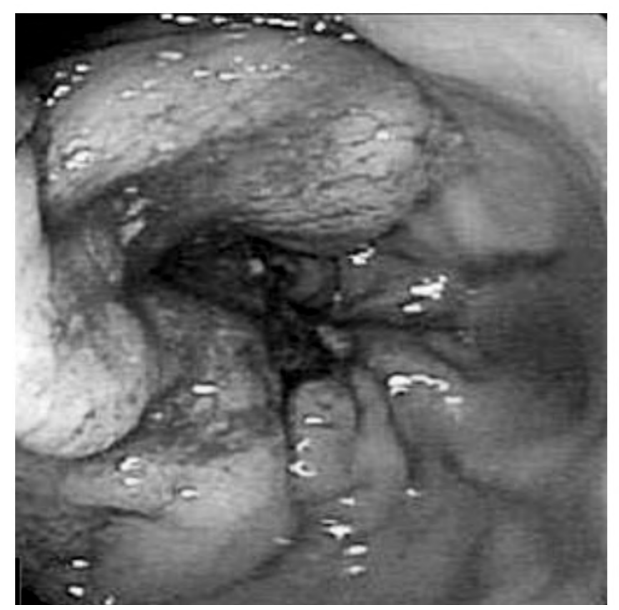

Fig. (3): Case of malignant rectal mass. multiplying intensity and extent scores. An immunohistochemical score of 5-6 was considered strong immunoreactivity and was given score 3, 3-4 was considered moderate and was given score 2 and 1-2 was considered weak and was given score 1 .

\section{Statistical analysis:}

The data were analyzed using Microsoft Excel 2010 and Statistical Package for Social Science (SPSS Version 22.0) for windows (SPSS IBM, Chicago, IL). Results were expressed as mean \pm SD with $95 \%$ confidence interval using mean for quantitative variables, frequencies and percentages for qualitative ones. $p<0.05$ was considered statistically significant. Quantitative data were analyzed by applying one-way analysis of variance (ANOVA) test forcomparison of the mean of more than two groups, while independent-samples $t$-test was used for comparison of the means of two groups. Chi-square test was used to compare proportions between two qualitative parameters.

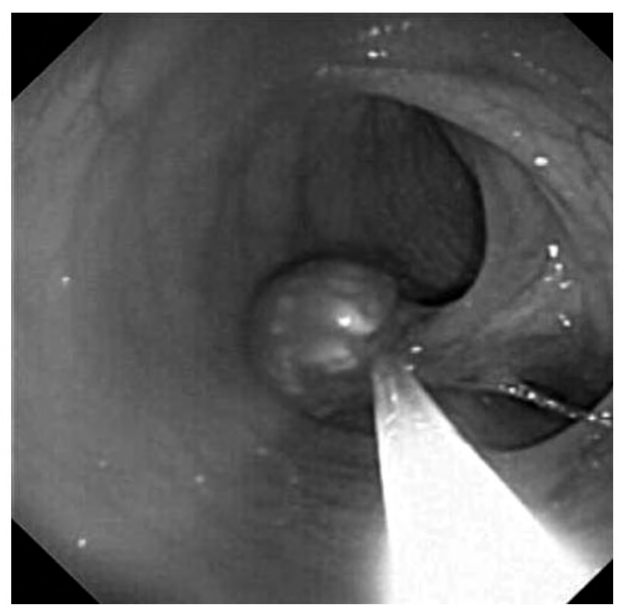

Fig. (2): Case of colonic polyp.

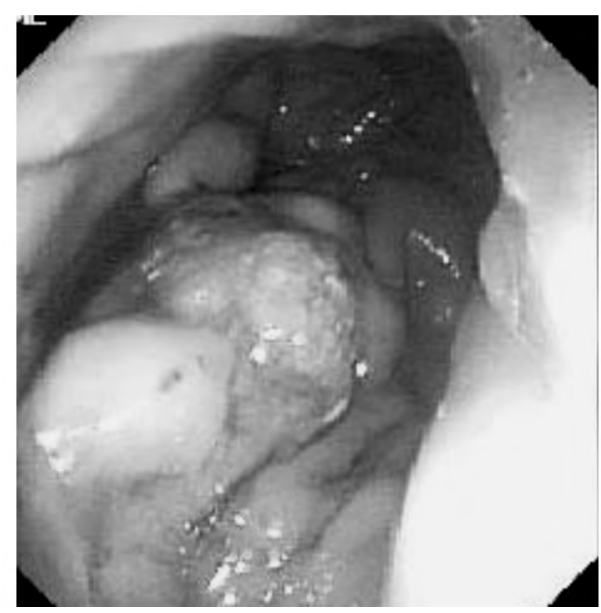

Fig. (4): Case of colonic mass. 

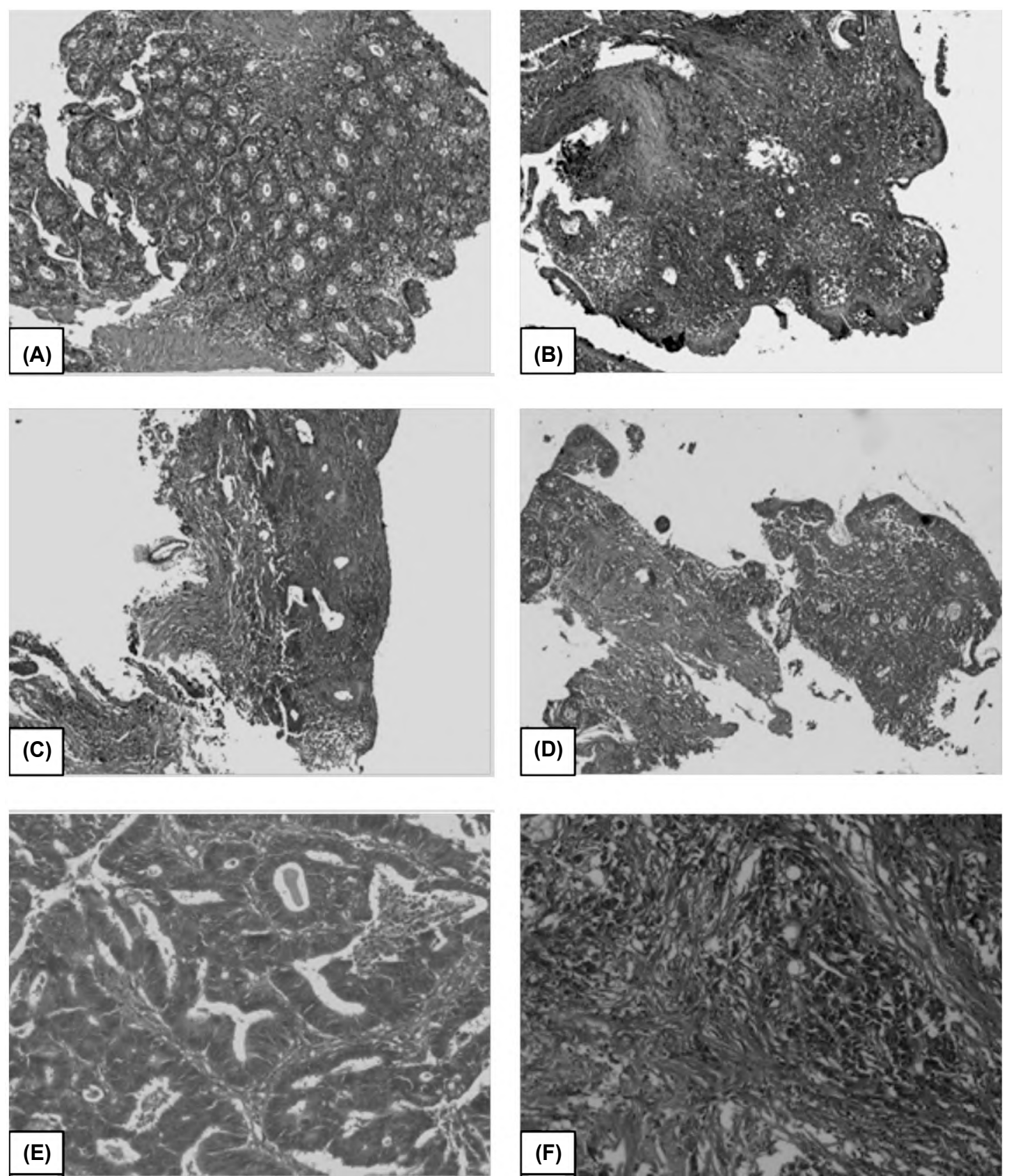

Fig. (5): Colonic sections stained with H \& E X100. (A) Control case of mild colitis, (B) UC case, (C) UC case with mild dysplasia, (D) A case of $\mathrm{CD}$, (E) A cases of well differentiated adenocarcinoma (GII) (H \& E, $\mathrm{X} 400)$, (F) A cases of poorly differentiated adenocarcinoma (GIII)) (H \& E, X400). 


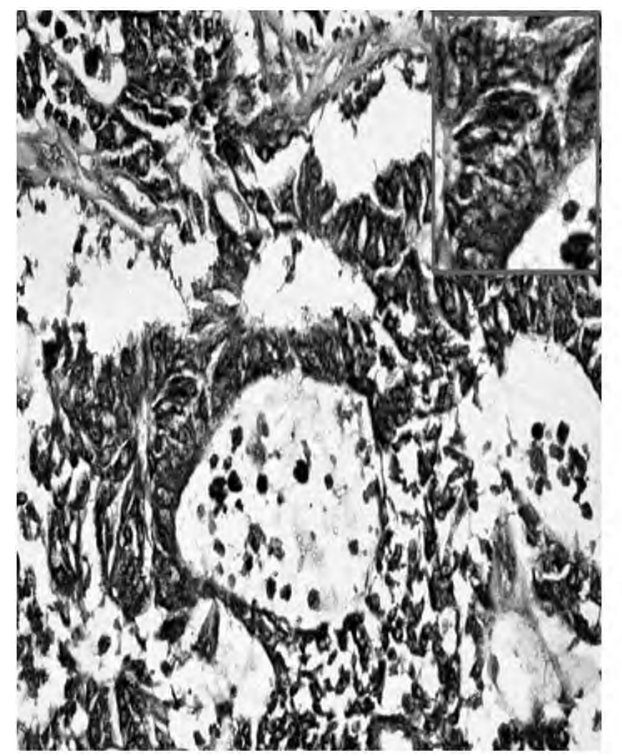

Fig. (6): A case of moderately differentiated adenocarcinoma, showing marked expression of CD133 immunostain in the cytoplasm of cells lining the colonic glands (red arrow) (H \& E X400).

\section{Results}

The demographic features of the whole studied patients and of each group are summarized in Table (1).

Bleeding per rectum was the most common presentation in the studied patients; presenting $35 \%$ of the total patients, malignant group (37.5\%), adenoma group (50\%). Weight loss was statistically highly significant $(p=0.03)$ in patients of malignant group (80\%). Mucorrhea was statistically highly significant $(p=0.006)$ in IBD group. Constipation and diarrhea was was statistically significant in control patients.

Fungating mass was the most the most common endoscopic endoscopic finding of CRC group $(62.5 \%)$ while ulceration was present $60 \%$ of IBD group and polypoid lesion was present $100 \%$ of adenoma group.

CEA was high elevated in CRC group ( $p=0.001)$ with high significant difference compared with other studied groups $(370.4 \mathrm{mg} / \mathrm{L}$ vs $6.8,6.9$ and $5.8 \mathrm{mg} / \mathrm{L}$, respectively).

Lgr5 was positive in 37 patients (92.5\%), 12 patients (60\%), 10 patients (50\%), 3 patients (15\%) in malignant, IBD, adenoma, and normal mucosa respectively, high statistically significance difference between groups at $p<0.001$.

CD133 was expressed in 40 patients (100\%), 12 patients $(60 \%), 14$ patients $(70 \%)$ and 3 patients

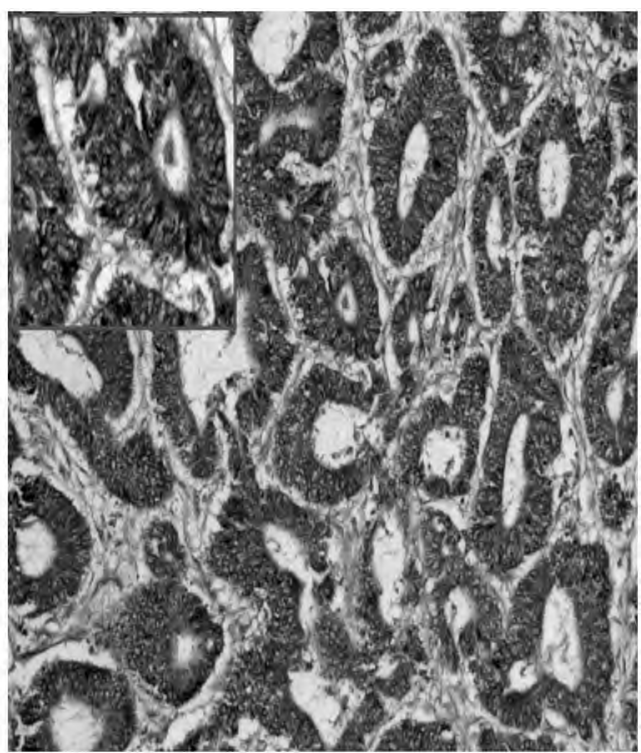

Fig. (7): A case of moderately differentiated adenocarcinoma (GII), showing marked expression of CD Lgr5 protein in the cytoplasm of cells lining the gland (red arrow) and crypt epithelium (black arrow) (IHC, DAB X100).

$(15 \%)$ in malignant, adenoma, IBD and control patients respectively, with high statistically significance between different groups at $p<0.001$. A very significant difference in CD133 expression was found between colorectal carcinoma and normal mucosa $(p<0.001)$.

4 cases out of $5(80 \%)$ of GI showed positive Lgr5 expression while 16 cases out of 18 (88.8\%) of GII showed positive Lgr5 and 17 cases out of $17(100 \%)$ of GIII showed positive Lgr5 expression. There is significant difference between GIII compared to GII and GI at $p<0.01$ and $p<0.05$ respectively.

As regard this correlation between immunoexpressionof CD133 andhistopathological grade, the intensity of CD133 was strong in GII (55.7\%) and GIII $(88.3 \%)$. There is significant difference between GIII compared to GII and GI at $p<0.01$ and $p<0.05$ respectively.

Four cases out of 5 of Dukes' A (60\%) were positive for Lgr5, 13 cases out of 15 of Dukes' B (86.6\%) and 20 cases out of 20 of Dukes' C (100\%) were positive for Lgr5. There is significance difference between Dukes' B and C comparing to Dukes' A at $p<0.01$ and $p<0.05$ respectively.

Three cases out of 5 of Dukes' A (60\%) were moderately positive for CD133, 1 case out of 15 of Dukes' B (66.7\%) showed strong expression of CD133 and 18 cases out of 20 of Dukes' C (90\%) were strong positive for CD133. 
Table (1): Age and sex of the studied groups.

\begin{tabular}{lcccccc}
\hline $\begin{array}{l}\text { Descriptive } \\
\text { parameters }\end{array}$ & $\begin{array}{c}\text { Control group } \\
\mathrm{N}=20\end{array}$ & $\begin{array}{c}\text { IBD group } \\
\mathrm{N}=20\end{array}$ & $\begin{array}{c}\text { Adenomas group } \\
\mathrm{N}=20\end{array}$ & $\begin{array}{c}\text { Malignant group } \\
\mathrm{N}=40\end{array}$ & $\begin{array}{c}\text { Total patients } \\
\mathrm{N}=100\end{array}$ & $\begin{array}{c}p \text { - } \\
\text { value }\end{array}$ \\
\hline $\begin{array}{l}\text { Age: } \\
\text { Mean } \pm \mathrm{SD}\end{array}$ & $55.3 \pm 15.02$ & $30.7 \pm 7.7$ & $40.2 \pm 12.7$ & $53.7 \pm 15.12$ & $44.975 \pm 18.17$ & $0.001 * *$ \\
Sex: & & & & & & \\
$\quad$ Female & $7(20.0 \%)$ & $8(22.9 \%)$ & $12(10.9 \%)$ & $16(45.7 \%)$ & $39(39 \%)$ & 0.9 \\
$\quad$ Male & $13(23.6 \%)$ & $12(21.8 \%)$ & $8(11.4 \%)$ & $24(43.6 \%)$ & $61(61 \%)$ & \\
\hline
\end{tabular}

Table (2): Clinical presentationin the studied groups.

\begin{tabular}{|c|c|c|c|c|c|c|}
\hline $\begin{array}{l}\text { Clinical } \\
\text { presentation }\end{array}$ & $\begin{array}{c}\text { Control group } \\
\mathrm{N}=20\end{array}$ & $\begin{array}{l}\text { IBD group } \\
\mathrm{N}=20\end{array}$ & $\begin{array}{c}\text { Adenomas group } \\
\quad \mathrm{N}=20\end{array}$ & $\begin{array}{c}\text { Malignant group } \\
\mathrm{N}=40\end{array}$ & $\begin{array}{l}\text { Total patients } \\
\qquad \mathrm{N}=100\end{array}$ & $\begin{array}{c}p- \\
\text { value }\end{array}$ \\
\hline Abdominal pain & $8(40.0 \%)$ & $5 \quad(25.0 \%)$ & $2(10.0 \%)$ & $5 \quad(12.5 \%)$ & $20(20.0 \%)$ & $0.04 *$ \\
\hline Bleeding per rectum & $0(0.0 \%)$ & $10(50.0 \%)$ & $10(50.0 \%)$ & $15(37.5 \%)$ & $35(35.0 \%)$ & $0.001 * *$ \\
\hline Constipation & $6(30.0 \%)$ & $0 \quad(0.0 \%)$ & $0 \quad(0.0 \%)$ & $3 \quad(7.5 \%)$ & $9 \quad(9.0 \%)$ & $0.003 * *$ \\
\hline Diarrhea & $6(30.0 \%)$ & $0 \quad(0.0 \%)$ & $5 \quad(25.0 \%)$ & $2(5.0 \%)$ & $13(13.0 \%)$ & $0.001 * *$ \\
\hline Anaemia & $0(0.0 \%)$ & $2(10.0 \%)$ & $1 \quad(5.0 \%)$ & $7 \quad(17.5 \%)$ & $10(10.0 \%)$ & 0.1 \\
\hline Weight loss & $0(0.0 \%)$ & $0 \quad(0.0 \%)$ & $2(10.0 \%)$ & $8 \quad(20.0 \%)$ & $10(10.0 \%)$ & $0.03 *$ \\
\hline Mucorrhea & $0(0.0 \%)$ & $3(15.0 \%)$ & $0 \quad(0.0 \%)$ & $0 \quad(10.0 \%)$ & $3 \quad(3.0 \%)$ & $0.006 * *$ \\
\hline
\end{tabular}

Table (3): Endoscopic findings in the studied groups.

\begin{tabular}{|c|c|c|c|c|c|c|}
\hline & $\begin{array}{l}\text { Control group } \\
\qquad N=20\end{array}$ & $\begin{array}{l}\text { IBD group } \\
\quad \mathrm{N}=20\end{array}$ & $\begin{array}{l}\text { Adenomas group } \\
\qquad \mathrm{N}=20\end{array}$ & $\begin{array}{l}\text { Malignant group } \\
\qquad N=40\end{array}$ & $\begin{array}{l}\text { Total patients } \\
\mathrm{N}=100\end{array}$ & $\begin{array}{c}p- \\
\text { value }\end{array}$ \\
\hline \multicolumn{7}{|l|}{ Site: } \\
\hline Rectum & $4 \quad(20 \%)$ & $6(30 \%)$ & $5(25 \%)$ & $10(25 \%)$ & $25(20 \%)$ & 0.7 \\
\hline Sigmoid & $0 \quad(0.0 \%)$ & $0(0.0 \%)$ & $5(25.0 \%)$ & $8 \quad(20 \%)$ & $13(13 \%)$ & $0.01 *$ \\
\hline Recto-sigmoid & $10(50 \%)$ & $8(40 \%)$ & $4(20 \%)$ & $9 \quad(22.5 \%)$ & $31(31 \%)$ & 0.08 \\
\hline Hepatic flexure & $6 \quad(30 \%)$ & $0(0.0 \%)$ & $3(15.0 \%)$ & $9 \quad(22.5 \%)$ & $18(18 \%)$ & 0.07 \\
\hline Caecum & $0 \quad(0.0 \%)$ & $0(0.0 \%)$ & $3(15.0 \%)$ & $4 \quad(10.0 \%)$ & $7(7 \%)$ & 0.1 \\
\hline Whole colon & $0 \quad(0.0 \%)$ & $6(30.0 \%)$ & $0(0.0 \%)$ & $0 \quad(0.0 \%)$ & $6(6 \%)$ & $0.001 * *$ \\
\hline $\begin{array}{l}\text { Endoscopic finding: } \\
\text { Mass }\end{array}$ & $0 \quad(0.0 \%)$ & $0(0.0 \%)$ & $0(0.0 \%)$ & $25(62.5 \%)$ & $25(20 \%)$ & $0.001 * *$ \\
\hline Angiodysplasia & $2(10.0 \%)$ & $0 \quad(0.0 \%)$ & $0 \quad(0.0 \%)$ & $0 \quad(0.0 \%)$ & $2(20 \%)$ & $0.04 *$ \\
\hline Polyp & $0 \quad(0.0 \%)$ & $0 \quad(0.0 \%)$ & $20(100.0 \%)$ & $\begin{array}{ll}0 & (0.0 \%)\end{array}$ & $20(20 \%)$ & $0.001 * *$ \\
\hline Hyperemia & $3 \quad(15.0 \%)$ & $6 \quad(30.0 \%)$ & $\begin{array}{ll}0 & (0.0 \%)\end{array}$ & $0 \quad(0.0 \%)$ & $9(20 \%)$ & $0.001 * *$ \\
\hline Ulceration & $\begin{array}{ll}0 & (0.0 \%)\end{array}$ & $12(60.0 \%)$ & $\begin{array}{ll}0 & (0.0 \%)\end{array}$ & $5 \quad(12.5 \%)$ & $17(20 \%)$ & $0.001 * *$ \\
\hline Stricture & $\begin{array}{ll}0 & (0.0 \%)\end{array}$ & $2(10.0 \%)$ & $\begin{array}{ll}0 & (0.0 \%)\end{array}$ & $10(25 \%)$ & $12(20 \%)$ & $0.008 * *$ \\
\hline Normal & $15(75.0 \%)$ & $0 \quad(0.0 \%)$ & $0 \quad(0.0 \%)$ & $0 \quad(0.0 \%)$ & $15(20 \%)$ & $0.001 * *$ \\
\hline
\end{tabular}

Table (4): Laboratory investigationsof the studied groups.

\begin{tabular}{|c|c|c|c|c|c|c|}
\hline & $\begin{array}{c}\text { Control group } \\
\mathrm{N}=20 \\
\text { Mean } \pm \text { SD }\end{array}$ & $\begin{array}{c}\text { IBD } \\
\mathrm{N}=20 \\
\text { Mean } \pm \text { SD }\end{array}$ & $\begin{array}{c}\text { Adenomas } \\
\mathrm{N}=20 \\
\text { Mean } \pm \mathrm{SD}\end{array}$ & $\begin{array}{c}\text { Malignant } \\
\mathrm{N}=40 \\
\text { Mean } \pm \text { SD }\end{array}$ & $\begin{array}{c}\text { Total patients } \\
\mathrm{N}=100 \\
\text { Mean } \pm \mathrm{SD}\end{array}$ & $\begin{array}{c}p- \\
\text { value }\end{array}$ \\
\hline \multicolumn{7}{|c|}{ Lab. investigation: } \\
\hline $\mathrm{HB}$ & $13.3 \pm 1.07$ & $9.9 \pm 1.01$ & $10.9 \pm .0 .59$ & $8.4 \pm 16.7$ & $11.4 \pm 12.9$ & $0.01 *$ \\
\hline TLC & $7.13 \pm 2.7$ & $8.79 \pm 2.7$ & $8.34 \pm 2.4$ & $7.94 \pm 2.1$ & $8.1 \pm 12.3$ & 0.1 \\
\hline PLT & $257.1 \pm 111.3$ & $215.6 \pm 46.2$ & $247.9 \pm 132.9$ & $214.15 \pm 87.9$ & $238.7 \pm 92.7$ & 0.1 \\
\hline ESR & $43.45 \pm 21.8$ & $61.4 \pm 25.96$ & $50.0 \pm 26.9$ & $66.7 \pm 27.9$ & $55.4 \pm 24.3$ & $0.02 *$ \\
\hline CEA & $6.8 \pm 3.05$ & $6.9 \pm 2.05$ & $5.8 \pm 2.09$ & $370.4 \pm 395.6$ & $97.5 \pm 86.9$ & $0.001 * *$ \\
\hline \multicolumn{7}{|c|}{ Stool finding: } \\
\hline Blood & $6(30.0 \%)$ & $4(20.0 \%)$ & $6(30.0 \%)$ & $7 \quad(17.5 \%)$ & $23(23 \%)$ & 0.5 \\
\hline Mucous & $4(20.0 \%)$ & $6(30.0 \%)$ & $4(20.0 \%)$ & $7 \quad(17.5 \%)$ & $21(21 \%)$ & 0.7 \\
\hline $\mathrm{EH}$ & $5(25.0 \%)$ & $6(30.0 \%)$ & $4(20.0 \%)$ & $9 \quad(22.5 \%)$ & $24(24 \%)$ & 0.8 \\
\hline Giardia & $4(20.0 \%)$ & $4(20.0 \%)$ & $4(20.0 \%)$ & $11(27.5 \%)$ & $23(23 \%)$ & 0.8 \\
\hline Pus & $1(5.0 \%)$ & $0(0.0 \%)$ & $2(10.0 \%)$ & $6 \quad(15.0 \%)$ & $9(9 \%)$ & 0.2 \\
\hline
\end{tabular}


Table (5): Immunohistochemical staining of Lgr5 (intensity \& extent) and CD133 of the studied groups.

\begin{tabular}{|c|c|c|c|c|c|c|}
\hline & $\begin{array}{c}\text { Control } \\
\mathrm{N}=20\end{array}$ & $\begin{array}{c}\text { IBD } \\
N=20\end{array}$ & $\begin{array}{c}\text { Adenomas } \\
\mathrm{N}=20\end{array}$ & $\begin{array}{l}\text { Malignant } \\
\mathrm{N}=40\end{array}$ & $\begin{array}{l}\text { Total patients } \\
\quad \mathrm{N}=100\end{array}$ & $\begin{array}{c}p- \\
\text { value }\end{array}$ \\
\hline \multicolumn{7}{|c|}{ Lgr5 intensity: } \\
\hline Negative & $17(85.0 \%)$ & $10(50.0 \%)$ & $8(40.0 \%)$ & $3 \quad(7.5 \%)$ & $38(38.0 \%)$ & $0.001 * *$ \\
\hline Weak & $3 \quad(15.0 \%)$ & $4 \quad(20.0 \%)$ & $4(20.0 \%)$ & $2 \quad(5.0 \%)$ & $13(13.0 \%)$ & 0.2 \\
\hline Moderate & $0 \quad(0.0 \%)$ & $6 \quad(30.0 \%)$ & $8(40.0 \%)$ & $8 \quad(20.0 \%)$ & $22(22.0 \%)$ & $0.01 *$ \\
\hline Strong & $0 \quad(0.0 \%)$ & $0 \quad(0.0 \%)$ & $0(0.0 \%)$ & $27(67.5 \%)$ & $27(27.0 \%)$ & $0.001 * *$ \\
\hline \multicolumn{7}{|l|}{ LRG5 extent: } \\
\hline Negative & $17(85.0 \%)$ & $10(50.0 \%)$ & $8(40.0 \%)$ & $3 \quad(7.5 \%)$ & $38(38.0 \%)$ & $0.001 * *$ \\
\hline Less5 & $0 \quad(0.0 \%)$ & $0 \quad(0.0 \%)$ & $0(0.0 \%)$ & $2 \quad(5.0 \%)$ & $2(2.0 \%)$ & 0.3 \\
\hline $5-25$ & $3 \quad(15.0 \%)$ & $2(10.0 \%)$ & $4(20.0 \%)$ & $0 \quad(0.0 \%)$ & $9 \quad(9.0 \%)$ & $0.05 *$ \\
\hline $25-50$ & $0 \quad(0.0 \%)$ & $2(10.0 \%)$ & $0(0.0 \%)$ & $0 \quad(0.0 \%)$ & $2 \quad(2.0 \%)$ & $0.04 *$ \\
\hline $50-75$ & $0 \quad(0.0 \%)$ & $6 \quad(30.0 \%)$ & $8(40.0 \%)$ & $8 \quad(20.0 \%)$ & $22(22.0 \%)$ & $0.01 *$ \\
\hline $75-100$ & $0 \quad(0.0 \%)$ & $\begin{array}{ll}0 & (0.0 \%)\end{array}$ & $0(0.0 \%)$ & $27(67.5 \%)$ & $27(27.0 \%)$ & $0.001 * *$ \\
\hline \multicolumn{7}{|l|}{ CD133: } \\
\hline Negative & $17(85.0 \%)$ & $6(30.0 \%)$ & $8(40.0 \%)$ & $0 \quad(0.0 \%)$ & $31(31.0 \%)$ & $0.001 * *$ \\
\hline Mild & $3 \quad(15.0 \%)$ & $8(40.0 \%)$ & $6(30.0 \%)$ & $3(7.5 \%)$ & $20(20.0 \%)$ & $0.01 *$ \\
\hline Moderate & $0 \quad(0.0 \%)$ & $6(30.0 \%)$ & $6(30.0 \%)$ & $11(27.5 \%)$ & $23(23.0 \%)$ & $0.05 *$ \\
\hline Strong & $0 \quad(0.0 \%)$ & $0(0.0 \%)$ & $0(0.0 \%)$ & $26(65.0 \%)$ & $26(26.0 \%)$ & $0.001 * *$ \\
\hline
\end{tabular}

Table (6): Correlation of Lgr5 score and histopathological grades in malignant group.

\begin{tabular}{llcc}
\hline \multirow{2}{*}{ Histopathological grade } & \multicolumn{3}{c}{ Lrg5 score staining } \\
\cline { 2 - 4 } & $\begin{array}{c}+, \text { Mild } \\
\text { (Score 1) }\end{array}$ & $\begin{array}{c}\text { ++, } \\
\text { Moderatescore (2) }\end{array}$ & $\begin{array}{c}+++, \text { Strong } \\
\text { (Score 3) }\end{array}$ \\
\hline Well differentiated (GI) N=5 & $1(25 \%)$ & $3(75 \%)$ & $0(0 \%)$ \\
Moderately differentiated (GII) N=18 & $1(16,6 \%)^{* *}$ & $6(33.4 \%)^{* *}$ & $9(50 \%)^{* *}$ \\
Poorly differentiated (GIII) N=17 & $0(0 \%)$ & $3(5.9 \%)^{* * \wedge}$ & $14(94.1 \%)^{* *}, \wedge$ \\
\hline
\end{tabular}

Cross tables, Pearson Chi-Square; $p<0.05$.

$*: p<0.01$ compared to GI group.

^: $p<0.05$ compared to GII group.

Table (7): Correlation of CD133 immunoexpression and histopathological grades in malignant group.

\begin{tabular}{llll}
\hline \multirow{2}{*}{ Histopathological grade } & \multicolumn{3}{c}{ Immunoexpression of CD133 staining } \\
\cline { 2 - 4 } & \multicolumn{1}{c}{+ , Mild } & ++ , Moderatescore &,+++ Strong \\
\hline Well differentiated (GI) N=5 & $3(60 \%)$ & $2(40 \%)$ & $0(0 \%)$ \\
Moderately differentiated (GII) N=18 & $3(16.6 \%)^{* *}$ & $5(27.7 \%)^{* *}$ & $10(55.7 \%)^{* *}$ \\
Poorly differentiated (GIII) N=17 & $0(0 \%)$ & $2(11.7 \%)^{* *}, \wedge$ & $15(88.3 \%)^{* *, \wedge}$ \\
\hline
\end{tabular}

Cross tables, Pearson Chi-Square; $p<0.05$.

$*: p<0.05$ compared to GI group.

$* *: p<0.01$ compared to GI group.

$\wedge: p<0.05$ compared to GII group.

Table (8): Correlation of Lgr5 score and histopathological stages in malignant group.

\begin{tabular}{lccc}
\hline \multirow{2}{*}{$\begin{array}{l}\text { Histopatho- } \\
\text { logical } \\
\text { grade }\end{array}$} & \multicolumn{3}{c}{ Lrg5 score immunoexpression } \\
\cline { 2 - 4 } & $\begin{array}{c}\text { Mild } \\
(\text { Score } 1)\end{array}$ & $\begin{array}{c}++, \text { Moderate- } \\
\text { score } \\
(\text { Score } 2)\end{array}$ & $\begin{array}{c}+++, \\
\text { Strong } \\
(\text { Score 3) }\end{array}$ \\
\hline Dukes' A N=5 & $0(0 \%)$ & $4(100 \%)$ & $0(0 \%)$ \\
Dukes' B N=15 & $0(0 \%)$ & $3(23.1 \%)^{*}$ & $10(76.9 \%)^{*}$ \\
Dukes' C N=20 & $0(0 \%)$ & $2(10 \%)^{*}, \wedge$ & $18(90 \%)^{*}, \wedge$ \\
\hline
\end{tabular}

Cross tables, Pearson Chi-Square; $p<0.05$.

$*: p<0.01$ compared to Duck A group.

$\wedge: p<0.05$ compared to Duck B group.
Table (9): Correlation of CD133 immunoexpressionand histopathological stagesmalignant group.

\begin{tabular}{llll}
\hline \multirow{2}{*}{$\begin{array}{l}\text { Histopatho- } \\
\text { logical } \\
\text { stages }\end{array}$} & \multicolumn{2}{c}{ Immunoexpression of CD133 staining } \\
\cline { 2 - 3 } & \multicolumn{2}{c}{+ Mild } &,++ Moderate-,+++ Strong \\
\cline { 2 - 3 } No. \% & No. \% & No. \% \\
\hline Duke A N=5 & $2(40 \%)$ & $3(60 \%)$ & $0(0 \%)$ \\
Duke B N=15 & $2(13.3 \%)$ & $3(20 \%)^{*}$ & $10(66,7 \%)^{*}$ \\
Duke C N=20 & $0(0 \%)$ & $2(10 \%)^{*}, \wedge$ & $18(90 \%)^{*}, \wedge$ \\
\hline
\end{tabular}

Cross tables, Pearson Chi-Square; $p<0.05$.

*: $p<0.01$ compared to Dukes' A group.

$\wedge: p<0.05$ compared to Dukes' B group. 


\section{Discussion}

Colorectal cancer is the fourth common tumor in Egypt after lymphoid, breast and urinary tumors [9]. Colorectal cancer develops from a dysplastic precursor lesion, regardless of whether it arises sporadically, in the setting of high-risk hereditary conditions, or in the context of chronic inflammation like Inflammatory Bowel Disease (IBD). In IBD, however, dysplasia can be polypoid or flat. In fact, the rather unusual macroscopic appearance and biologic behavior of dysplasia in IBD have stimulated a good deal of research into the natural history and molecular pathogenesis of CRC in patients with IBD [10]. Cancer stem cell theory in CRC has been investigated and it is based on evidence that only a small subset of cells, the CSCs, within the tumor population, can initiate and sustain tumor growth and several stem cell markers have been studied [11]. Several markers have been identified as solid cancer stem cell markers. CD133 is a transmembrane pentaspan protein which was initially described as a surface antigen specific for human hematopoietic stem cells. Indeed, CD133 alone or in a combination with other markers is currently used for the isolation of stem cells from numerous tissues, such as bone marrow, brain, kidney, prostate, liver, pancreas, and skin. Furthermore, investigators have used monoclonal antibodies to CD133 for the identification and isolation of a putative cancer stem cell population from malignant tumors of brain, prostate, liver, pancreas, lung, and colon [12]. On the other hand protein Glycoprotein Coupled Receptors (GCRs) have been investigated to be closely associated with tumorgenesis [13]. Lgr5 which is the one of (GCRs) members proved to be a stem cell marker [14].

This prospective study was conducted on 100 patients presenting with colonic symptoms, attending to Gastrointestinal Endoscopy Unit in Nasser Institute for research and treatment Hospital. This study was aiming to assess the expression of CD133 and Lgr5 in pre-malignant (adenomatous polyps and IBD), malignant colorectal lesions and normal colonic mucosa by immunohistochemical staining.

According to the immunohistochemical results, lgr5 was detected as brown cytoplasmic granules with different expression pattern in normal colonic mucosa, adenoma and carcinoma. Our results showed that Lgr5 protein was strongly positively (score 3 ) in $67.7 \%$ of cases $(27 / 40)$, moderately (score 2) in $20 \%$ of cases (8/40) and mild (score 1 ) in $5 \%$ of cases $(2 / 40)$ of colorectal carcinomas respectively, with high statistically significance difference between groups at $p<0.001$. Statistically speaking a significant correlation was found between score of lgr5 expression and the type of the lesion as the score increases with progression of lesion from adenoma to carcinoma ( $p$-value <0.01). This was in agreement with Ranih et al., [15] who stated that Lgr5 expression was detected in CRC cases and the immunohistochemical pattern showed that 8 cases $(23.5 \%)$ were score group (1), 8 cases (23.5\%) were score group (2) and 18 cases (53\%) were score group (3). This was in agreement with Fan et al., [14] who stated that $54 \%$ of colorectal carcinoma cases showed score group (3) of Lgr5 expression. This means that Lgr5 expression might be involved in colorectal carcinogenesis.

In the current study, as regard the tumor grading, Lgr5 immunoexpression in CRC group. Three cases $(80 \%)$ of GI, 16 cases $(88.8 \%)$ of GII and 17 cases $(100 \%)$ of GIII with high statistcal significant difference between GIII compared to GII and GI at $p<0.01$ and $p<0.05$ respectively. Thisresult can in agreement with Ranih et al., [15] who stated that there is correlation between lgr5 score and the grade of CRC. Out of 21 cases of moderately differentiated carcinoma, 4 cases $(19 \%)$ showed score group (1), 4 cases (19\%) showed score group (2) and 13 cases (62\%) showed score group (3) while out of 13 cases of poorly differentiated carcinoma, 4 cases $(30.8 \%)$ showed score group (1), 4 cases $(30.8 \%)$ showed score group (2) and 5 cases (38.4\%) showed score group (3). These results were in disagreement with Fan et al., [14] who found that no correlation was found between Lgr5 score and the grade of CRC as $34 \%$ of grade II showed score 1, $14.9 \%$ of grade II showed score 2 and $4.5 \%$ showed score 3 . In grade III $86.6 \%$ of cases showed score (1) and $13.4 \%$ of cases showed score (2) and no cases showed score (3). This current study can in disagreement with Takeda et al., [16] that found Lgr5 expression was not correlated to the degree of differentiation of CRC cases.

These results were in contrast with Simon et al., [17] that found Lgr5 was correlated significantly with tumor grade in gastric adenocarcinoma ( $p$ value $<0.01$ ).

Concerning the expression of CD133 in CRC cases, the present study revealed a significant difference between colorectal carcinoma and normal mucosa $(p<0.001)$. CD133 was positive in $15 \%$ of cases $(3 / 20)$ of normal mucosa (control cases). CD133 protein was strongly positively in intensity in $65 \%$ of cases (26/40), moderately $27.5 \%$ of cases (11/40) and mild intensity of CD133 in $7.5 \%$ of cases $(3 / 40)$ of the colorectal carcinomas 
respectively, with high statistically significance $(p<0.001)$. These findings are in agreement with Shamaa et al., [18] who revealed mild expression in $(11.4 \%)$ of cases and strong expression in $(88.6 \%)$ of cases. These findings are in agreement with Takahashi et al., [19] and by Yang et al., [20] However; our results are in contrary to those of Hongo et al., [24], Choi et al., [23], Horst et al., [21] and Kojima et al., [22] . This can be explained by the difference in the sample size; the studies which disagreed with our results had larger sample size.

These findings are in agreement with those detected by Wang et al., [25] found that high CD133 expression was significantly associated with moderately and poorly differentiated CRC. In contrast Shamaa et al., [18] who stated that no significant relation between CD133 expression and histologic grade and also with that found by Coco et al., [27], Hongo et al., [24], (Wang et al., [25]), Takahashi et al., [19], Choi et al., [23], Horst et al., [21] and Saigusa et al., [26].

As regard Dukes' stagingand Lgr5 expression our results showed that four cases out of 5 of Dukes' A (60\%) were positive for Lrgr5, 13 cases out of 15 of Dukes' B $(86.6 \%)$ showed immunoreactivity for Lgr5, and 20cases out of 20 of Dukes' C (100\%) were positive for Lgr5 with statistcally significance difference $(p<0.01)$. There was a significant correlation between score of Lrg5 and the stage of CRC ( $p$-value <0.05). These results suggest that $\operatorname{Lrg} 5$ expression perhaps play a role not only in tumor initiation but also in the progression of the tumor. These results in agreement with Ranih et al., [15] that showed, 66.7\% showed Lgr5 score group (1), 2 cases (22.2\%) showed Lgr5 score group (2) and 1 case $(11.1 \%)$ showed Lgr5 score group (3), out of 6 cases of stage III, 1 case (16.7\%) showed Lgr5 score group (1), 2 cases (33.3\%) showed Lgr5 score group (2) and 3 cases (50\%) showed Lgr5 score group (3). Out of 19 cases of stage IV, 1 case (5.3\%) showed Lgr5 score group (1), 4 cases (21\%) showed Lgr5 score group (2) and 14 cases $(73.7 \%)$ showed Lgr5 score group (3). Merlos et al., [28], Takahashi et al., [19], and Uchida et al., [29], also found increased Lgr5 expression in advanced stages of CRC cases.

Concerning the expression of CD133 in CRC cases in correlation to Dukes' stage, there is three cases out of 5 of Dukes' A (60\%) were moderately positive for CD133, 1 cases out of 15 of Dukes' B (66.7\%) showed strong expression of CD133, and 18 cases out of 20 of Dukes' C (90\%) were stronge positive for CD133. This is in contrast with results of Shamaa et al., [18], Wang et al., [25], Takahashi et al., [19], Choi et al., [23], Horst et al., and Kojima et al., [22] that found no significant relation between CD133 expression and modified Dukes'. Horst et al., [27] reported significant relation with $\mathrm{N}$ and $\mathrm{M}$ stage. The studies having different results from ours are much larger in the number of patient and also Coco et al., [32] studies have different cut-off used to discriminate low and high expression.

\section{Conclusion:}

As stem cell marker of cells with intestinal differentiation, Lgr5 and CD133 was presented with significant increased expression with progression from normal colon towards CRC. Lgr5 expression and CD133 was positively correlated with stage of CRC suggesting its possible involvement in colorectal tumorigenesis progression and pateint's outcome.

\section{References}

1- CLARKE M.F., DICK J.E., DIRKS P.B., et al.: Cancer stem cells-Perspectives on current status and future directions: AACR Workshop on Cancer Stem Cells. Cancer Res., 66: 9339-44, 2006.

2- HILL R.P. and PERRIS R.: "Destemming" cancer stem cells. J. Natl. Cancer Inst., 99: 1435-40, 2007.

3- SANDERS M.A. and MAJUMDAR A.P.: Colon cancer stem cells: Implications in carcinogenesis. Front Biosci. (Landmark Ed) 2011, 16: 1651-62, 2001.

4- BECKER L., HUANG Q., MASHIMO H., et al.: Lgr5, an intestinal stem cell marker, is abnormally expressed in Barrett's esophagus and esophageal adenocarcinoma. Dis. Esophagus, 23: 168-74, 2010.

5- FEMIA A.P., DOLARA P., SALVADORI M. and CADERNI G.: Expression of LGR-5, MSI-1 and DCAMKL1, putative stem cell markers, in the early phases of 1,2dimethylhydrazine-induced rat colon carcinogenesis, correlation with nuclear 3 -catenin. B.M.C. Cancer, 13, 48, 2013.

6- SINGH S.K., CLARKE I.D., TERASAKI M., et al.: Identification of a cancer stem cell in human brain tumors. Cancer Res., 63: 5821-8, 2003.

7- O'BRIEN C.A., POLLETT A., GALLINGER S., et al.: A human colon cancer cell capable of initiating tumour growth in immunodeficient mice. Nature, 445: 106-10, 2007.

8- RICCI-VITIANI L., LOMBARDI D.G., PILOZZI E., et al.: Identification and expansion of human colon-cancerinitiating cells. Nature, 445: 111-5, 2007.

9- MOKHTAR N., GOUDA I. andADEL I.: Cancer pathology registry 2003-2004 and time trend analysis. In: Mokhtar N., editor; Gouda I., editor; Adel I., editor. Malignant digestive system tumors. NCI, Elsheraa Press; Cairo, pp. 55-67, 2007.

10- C. Canavan, K.R. Abrams and J. MAYBERRY: Metaanalysis: Colorectal and small bowel cancer risk in patients 
with Crohn's disease. Alimentary Pharmacology \& Therapeutics, 23: 1097-104, 2006.

11- EROS FABRIZI, SIMONA DI MARTINO, FEDERICA PELACCHI and LUCIA RICCI-VITIANI: Therapeutic implications of colon cancer stem cells. World J. Gastroenterol., 21; 16 (31): 3871-7, 2010.

12- SHMELKOV S.V., BUTLER J.M., HOOPER A.T., et al.: CD133 expression is not restricted to stem cells, andboth CD133+ and CD133-metastatic colon cancer cells initiate tumors. J. Clin. Invest., 118: 2111-20, 2008.

13- BARKER N., VAN ES J.H., KUIPERS J., et al.: Identification of stem cells in small intestine and colon by marker gene Lgr5. Nature, 25: 1003-7, 2009.

14- FAN Y., CHONG Y.S., CHOOLANI M.A., CREGAN M.D. and CHAN J.K.Y.: Unravelling the mystery of stem/ progenitor cells in human breast milk. PLoS One, 5: e14421. doi: 10.1371/journal.pone.0014421, 2010.

15- RANIH Z., NASHWA M., GHADA, et al.: Significance of Stem Cell Marker Lgr5 Expression in Colorectal Carcinogenesis. Med. J. Cairo Univ., Vol. 81, No. 2, December: 171-176, 2013 www.medicaljournalofcairouniversity. net, 2013.

16- TAKEDA K., KINOSHITA I., SHIMIZU Y., et al.: Expression of LGR5, an intestinal stem cell marker, during each stage of colorectal tumorigenesis. Anticancer. Res., 31: 263-70, 2011

17- SIMON E., DIANA P., CHRISTINE B., et al.: The Spatial Distribution of LGR5+ Cells Correlates With Gastric Cancer Progression. PLoS One, 7: 4, 2012.

18- SAMEH SHAMAA, NADIA ATWAN, MOHAMED ABDEL WAHAB, et al.: Colorectal Cancer Stem Cells: Relation to Clinico-pathological Features and Prognosis. Journal of American Science, 12 (1), 2016.

19- TAKAHASHI H., ISHII H., NISHIDA N., et al.: Significance of Lgr5 (+ve) cancer stem cells in the colon and rectum. Ann. Surg. Oncol., 18: 1166-74, 2011.

20- YANG K., CHEN X., ZHANG B., et al.: Is CD133 a biomarker for cancer stem cells of colorectal cancer and brain tumors? A meta-analysis. Int. J. Biol. Markers, 26 (3): 173-80, 2011.

21- HORST D., SCHEEL S.K., LIEBMANN S., et al.: The cancer stem cell marker CD133 has high prognostic impact but unknown functional relevance for the metastasis of human colon cancer. J. Pathol., 219: 427-34, 2009.

22- KOJIMA M., ISHII G., ATSUMI N., et al.: Immunohistochemical detection of CD133 expression in colorectal cancer: A clinicopathological study. Cancer Sci., 99 (8): 1578-83, 2008.

23- CHOI D., LEE H.W., HUR K.Y., et al.: Cancer stem cell markers CD133 and CD24 correlate with invasiveness and differentiation in colorectal adenocarcinoma. World J. Gastroenterol., 15 (18): 2258-64, 2009.

24- HONGO K., KAZAMA S., SUNAMI E., et al.: Immunohistochemical detection of CD133 is associated with tumor regression grade after chemoradiotherapy in rectal cancer. Med. Oncol., 29: 2849-57, 2012.

25- WANG T., YEOH K., SALTO-TELLEZ M., et al.: Lgr5 expression is absent in human premalignant lesions of the stomach. Gut., 10: 1136, 2012.

26- SAIGUSA S., TANAKA K., MD 1, TOIYAMA Y., et al.: Correlation of CD133, OCT4, and SOX2 in rectal cancer and their association with distant after chemoradiotherapy. Ann. Surg. Oncol., 16: 3488-98, 2009.

27- COCO C., ZANNONI G.F., CAREDDA E., et al.: Increased expression of CD133 and reduced dystroglycan expression are strong predictors of poor outcome in colon cancer patients. Journal of Experimental \& Clinical Cancer Research, 31: 71, 2012.

28- MERLOS S.A., BARRIGA F.M., JUNG P., et al.: The intestinal stem cell signature identifies colorectal cancer stem cells and predicts disease relapse. Cell Stem Cell, 8: 511-24, 2011.

29- UCHIDA H., YAMAZAKI K., FUKUMA M., et al.: Overexpression of leucine-rich repeat-containing $\mathrm{G}$ protein-coupled receptor 5 in colorectal cancer. Cancer Science, 101: 1731-7, 2010. 


\section{دراسة هستوكيميائية للخلايا الجذامية السرطانية القولونية

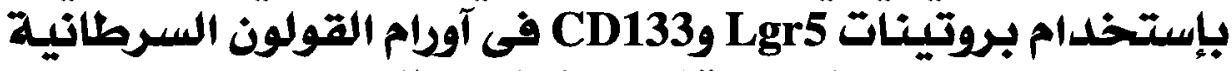 والسابقة لحدوث السرطان آوتان}

يعد سرطان القولمن المدم الرابع الآكثر شيوعا فى مصر ويآتى بعد آقدام الغدد الليمفاوية قآقدام الثدى قآودام الجهاز البولى.

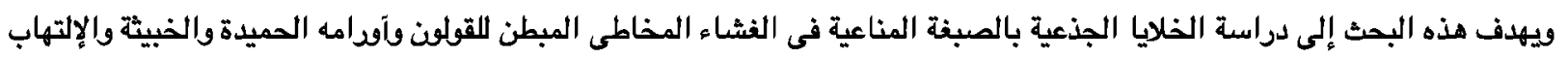

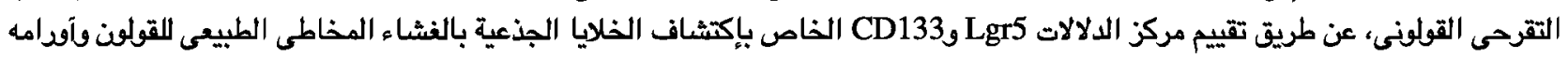

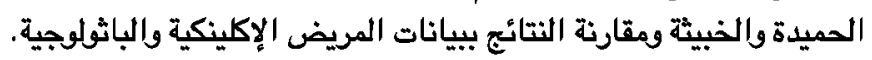

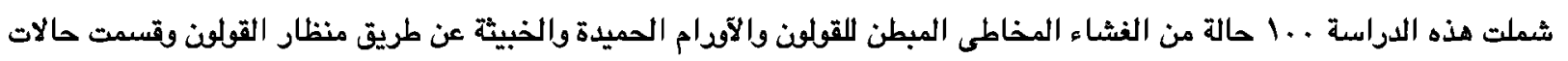

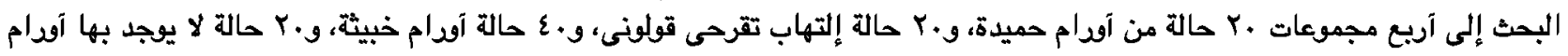
بغرض المقارنة.

ظهر من هذه الدراسة آن يتم ظهود بروتينات Lgr5 وCD133 فى خلايا الآودام الحميدة والإلتهاب التقرحى القولونى ويزداد ظهوده تدريجيا

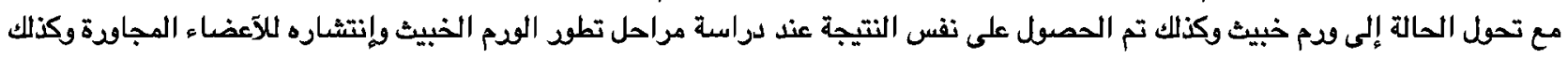

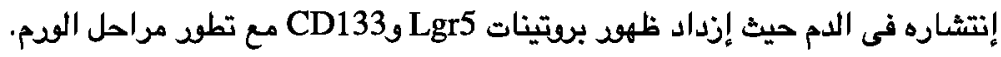

من هذه الدراسة نستتج آن بروتينات CD133 Lgr5 هى برتينات تدخل فى سلسلة تصويل إصابات القولون الحميدة إلى خبيثة ويزداد

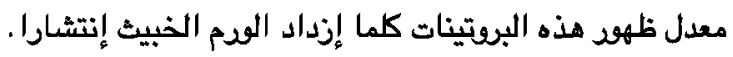

